\section{A Shift but not a Change!}

T he switch from one Editor in Chief to another might well have escaped the attention of most readers - but one of the duties inherent in the publication of this journal is to report that a shift has taken place in the accountability of the 2 Editors in Chief with effect from 1st January 1999. However, this does not imply a change but rather continuity at management level, as the 2 Editors in Chief have shared the work in recent years and have consistently coordinated their efforts towards a bilingual journal. In other words, the shift is a pure formality and would not in itself be seen as a motive for an editorial.

The 2 Editors would therefore like to take this opportunity to address a special wish combined with an appeal to our readers.

A scientifically oriented journal is characterized primarily by research results from the different areas of the respective specialty. Although these often have no direct bearing on practical applications, they are most certainly of importance to its longterm development. In our own context, special significance is due to case reports: The presentation of unusual diagnostic findings or original solutions to complex treatment tasks plays a vital role in enlivening our journal and giving it a practical aspect. It is here that the wealth of experience gained by practising orthodontists is needed to stimulate a lively interchange of ideas, innovations or proven therapies. In view of the high standard of documentation in many practices, such case reports should be available with good-quality photographic material.

We hope this appeal may motivate readers to "dig out a few hidden treasures".

\section{Wechsel, aber kein Wandel}

Q icherlich wäre die vorgenommene Veränderung in der Schriftleitung den meisten Lesern unbemerkt geblieben. Es gehört jedoch zur Informationspflicht der Zeitschrift, mitzuteilen, daß ab 1. Januar dieses Jahres ein Wechsel in der Verantwortlichkeit der beiden Schriftleiter stattgefunden hat. Dies bedeutet aber keinen Wandel, sondern weiterhin Kontinuität im Management, da sich beide Schriftleiter in den vergangenen Jahren die Arbeit geteilt haben und in ständiger kollegialer Rücksprache standen, um das Projekt der Zweisprachigkeit zu realisieren. Der Wechsel ist demnach nur ein formaler Vorgang und wäre für sich allein kein Grund für ein Editorial.

Beide Schriftleiter wollen deshalb diesen redaktionellen Hinweis zum Anlaß nehmen, einen Wunsch und zugleich Aufruf an die Leser zu richten.

Eine wissenschaftlich orientierte Zeitschrift wird vornehmlich durch die Forschungsergebnisse aus den verschiedenen Bereichen des Faches geprägt; diese haben häufig keinen unmittelbaren praktischen Bezug, sicherlich aber Bedeutung für dessen langfristige Entwicklung. Insofern kommt den Fallberichten eine besondere Bedeutung zu: Die Darstellung ungewöhnlicher diagnostischer Befunde oder origineller Lösungen schwieriger Behandlungsaufgaben trägt wesentlich zur Lebendigkeit und Praxisnähe unserer Zeitschrift bei. Hier ist der große Erfahrungsschatz der praktizierenden Kieferorthopäden gefragt, so daß auf diesem Wege ein reger Austausch an Ideen, Innovationen oder bewährten Therapien stattfinden kann. Bei der guten Dokumentation in vielen Praxen dürften solche Fallberichte in guter Bildqualität möglich sein.

Wir hoffen, daß dieser Aufruf als „Motivationsspritze" dient, um ,schlummernde Schätze" zu heben.

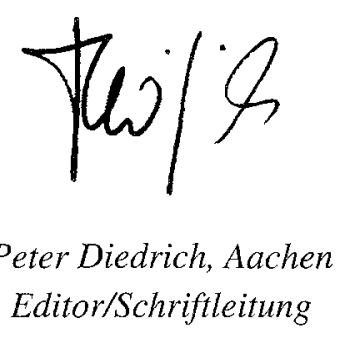

